ÇOMÜ Uluslararası Sosyal Bilimler Dergisi 4 (2), 265-287 , 2019 COMU International Journal of Social Sciences 4 (2), 265-287 , 2019

\title{
Asya Kıtasında Hak ve Özgürlük Mücadelesinde Kadın Siyasal Figürler: Değişim Mümkün müdür?
}

Soner HAMZAÇEBİ *

$\ddot{O} z$

Kadınlar; toplumsal, ekonomik ve siyasal alanlardaki hak kazanımlarına 20. Yy'de sahip olmuşlardır. Ancak bu haklar günümüzde istenilen seviyeye ulaşamamıştır. Özellikle de kadınların siyasal haklarının daha kısıtlı olması, dünya genelinde kadınların siyasal katılım oranın düşük kalmasına neden olmuştur. Hâlbuki kadınların siyasal oluşumlar içinde olması, kadın sorunun çözümü için önemli bir adımdır. Bu nedenle kadın sorununun çözümü için kadınların siyasetteki temsil sayısının artması, kadın siyasetçi kotalarının arttırılması ve kadınların daha aktif siyasi oluşumlar içinde olmaları gerekmektedir. Böylelikle kadınların siyasal yaşama katılımı ve kamusal kararlarda karar almaları daha kolay olacaktır. Ancak bu durum her toplum için aynı koşulları taşımamaktadır. Örneğin Asya uluslararası politikasında kadın aktörler bulundukları siyasi konumları itibariyle dünya gündeminde önemli bir yer tutmaktadır. Bilhassa İkinci Dünya Savaşı sonrası yeni bir siyasi değişim sürecine giren Çin ve Myanmar'da; kadın aktörlere yönelik baskılar üst seviyelere ulaşmıştır. Bu iki ülkede toplumu ilgilendiren konularda sadece erkek aktörlerin kararlar alması kadın aktörleri siyasetin dışına itmektedir. Bu bağlamda çalışmada genel olarak; Asya toplumunda kadın siyasal figürlerin genel bir değerlendirilmesi yapılacak, Myanmar ve Doğu Türkistan’n siyasal dönüşümleri anlatılacak ve çalışmanın ana konusunu oluşturan Aung San Suu Kyii ve Rebiya Kaderr’in yürütmeye çalıştıkları demokrasi mücadelelerine dikkat çekilecektir.

Anahtar Kelimeler: Kadın Aktörler, Feminizm, Myanmar, Doğu Türkistan, Siyasi Dönüşümler.

\section{Women Political Figures In the Struggle for Right and Freedom In Asian Countries: Is the Change Possible?}

\begin{abstract}
Women; have gained social, economic and political rights in 20 centuries. However, these rights have not reached the desired level even today. The fact that women's political rights are more limited has caused women's political participation rate to remain low throughout the world. Whereas; The fact that women are in political formations is a prerequisite for the solution of women's problem. For this reason, in order to solve the problem of women, the number of women's representation in politics should be increased, female quotas should be increased and women should be more active in political formations. Thus, women's participation in political life and decisions in public decisions will be easier. However, this situation does not have the same conditions for every society. For example, in Asian international politics, women actors have an important place in the world's agenda due to their political
\end{abstract}

\footnotetext{
* Doktora Öğrencisi, Karadeniz Teknik Üniversitesi, Sosyal Bilimler Enstitüsü, Uluslararası İlişkiler Bölümü, sonerhamzacebi@gmail.com
} 
positions. In China and Myanmar, which entered into a new process of political change especially after the Second World War; the pressures towards women actors reached higher levels. In these two countries, only male actors take decisions on issues of public interest, pushing women actors out of politics. In this context, the study generally; A general evaluation of female political figures will be made in Asian society, the political transformations of Myanmar and East Turkestan will be explained and the struggles of Aung San Suu Kyii and Rebiya Kaderr who are the main subjects of his work will be pointed out in the struggle for democracy.

Keywords: Women Actors, Feminism, Myanmar, Eastern Turkestan, Political Transformations.

\section{GIiRIŞ}

Çağdaşlaşma konusunda devletlerin en fazla önem verdiği ve ihtiyaç duyduğu olgu hiç şüphesiz demokrasi olmuştur. Öyle ki gelişmiş Batılı devletlerin demokrasi anlayışı, iç ve dış politikalarına yön veren bir olgudan öte bir yaşam biçimi halini almıştır. Böylece gelişmiş Batılı devletler; siyasi, iktisadi ve kültürel bağlarını geliştirme bakımından var olan zenginliklerine daha fazlasını ekleme imkanına sahip olmuşlardır. Öte yandan, özgürlükler açısından demokrasi anlayışlarını yasalar ile koruyarak halklarına demokrasi anlayışını aşılamışlardır. Teoride kadın- erkek ayrımı yapılmadan herkesin gerek siyasi gerek iktisadi gerekse de kültürel faaliyetler içinde bulunmalarına imkân sağlamışlardır. Ancak Batı dünyasında toplumsal eşitsizliğin (kadın-erkek ayrımı) ortadan kalkma süreci bir anda gerçeklemiş bir durum değildir. Batının geçmiş tarihinde toplumsal eşitsizliğin yaşandığını görmek mümkündür. Feminist alanda çalışmalar yapan J. Ann Tickner, Machiavelli'nin Prens adlı eserine atıfta bulunarak; neden uluslararası alanda devletleri yönetenlerin, iktidarı elinde tutanların, güç sahibi olanların prenslerin (erkeklerin) olduğunu, prenseslerin (kadınların) ise; neden geri planda kalarak rutin işlerde uğraştığını sorgulamaktadır. ${ }^{2}$ Batı dünyasında kadın-erkek eşitsizliği bugünün sorunu değildir. Sistematik olarak geçmişten beri var olan bu sorun, bugün uluslararası ilişkiler disiplini içinde feminist hareket olarak yer almaktadır. Feminizm, kadın-erkek ayrımcılığına karşı durarak; kadınların, erkekler gibi ekonomik, siyasal ve sosyo-kültürel oluşumlar içinde baskı altında kalmamalarını savunmaktadır.

Feminist çalışmaların ilki, 18.Yy'de İngiliz düşünür Mary Wollstonecraft, Kadın Haklarının Gerekçelendirilmesi (A Vindication of the Rights of Woman) adlı çalışmasında kadınların köle olmadığı savunmasıyla başlamıștır. Yazara göre; kadınların köle olarak kalmalarının nedeni eğitim seviyelerindeki yetersizlikten kaynaklanmaktadır. Eğitimli kadın birey, kendi hakkını karşısındakine karşı koruyabilir, olanı değil olması gerekenin savunuculuğunu yapabilir, aksi taktirde kendisine dayatılanı kabul etmek zorunda kalabilir. Bu nedenlerden dolayı, Wollstonecraft, feminizmde en önemli unsurun kadının eğitilmesi olduğunu savunmuştur. ${ }^{3}$

2- J. Ann Tickner "Searching for the Princess? Feminist Perspectives in International Relations." Harvard International Review, Cilt 21, Sayı 4, 1999, pp. 44-48.

3- Özlem, Tür, ve Aydın Koyuncu, Çiğdem, “Feminist Uluslararası İlişkiler Yaklaşımı: Temelleri, Gelişimi, Katkı 
Kadın-Erkek ayrımın yaşandığı 19. ve 20. Yy’de ise; artık kadınlar erkekler gibi eşit statü, eşit haklar ve özgürlüklere ulaşmak için mücadele vermeye başlamıştır. Bu mücadeleler feminist akımın hızla yayılmasına neden olmuştur. Feministler en büyük kazanımlarını ise, 20. ve 21. Yy'ler arasında elde etmişlerdir. Bu tarihler arasında kadınların özel alanlarda olduğu gibi kamusal alanlarda ve siyasi oluşumlar içinde de olduğunu görmekteyiz. Kadınlar büyük şirketlerde yöneticilik yapı̆̆ı gibi ülke yönetimlerinde de yer almaya başlamıştır. Örneğin; Margaret Thatcher (İngiltere Başbakanı), Golda Meir (İsrail Başbakanı), Madeleine Albright, (ABD Dışişleri Bakanı), İndira Priyadarşini Gandhi (Hindistan Başbakanı), Benazir Bhutto (Pakistan Başbakanı), Tsai Ing-wen (Tayvan Cumhurbaşkanı), Sheikh Hasina Wajed (Bangladeş Başbakanı) ve Park GeunHye (Güney Kore Başbakanı) gibi kadın aktörler Batı ve Asya siyasetinde dikkat çeken kadın aktörlerdir. ${ }^{4}$ Ancak Asya toplumunun genel karakteristik özelliğine baktığımızda bu bölgenin ataerkil bir yönetim biçimine sahip olduğunu söyleyebiliriz. Erkeğin egemen olduğu Asya ve Orta Asya toplumunda; toplumsal eşitlik, kadın hakları savunuculuğu ve demokratik anlayış Avrupa ülkelerinde olduğu gibi geniş bir alana yayılamamıştır. Bunun nedenlerine baktığımızda, sömürge olmaları, tarihsel süreçleri, etnik nedenlere bağlı çatışmaları, askeri darbeler ve okuryazar oranın düşük olması önemli bir yer tutmaktadır.

İkinci Dünya Savaşı ve Soğuk Savaş sonrası sömürge olmaktan kurtulan ve yeni bağımsızlıklarını kazanan Asya ve Orta Asya’nın bazı devletleri, demokrasi sürecine geçerken bazıları da askeri rejimlerce yönetilmektedir. Bazı devletler ise, demokrasi ile yönetilmelerine rağmen; özerklik verdikleri bölgelerinde katı kurallar uygulamaktadırlar. Demokratik bir siyasi anlayışla yönetilmeyen Myanmar ve Doğu Türkistan'da, siyasi karar alıcılar bölgelerinde Kyii'nin ve Kaderr'in toplumsal düzeni bozduğunu ileri sürmüşlerdir. Bunu da; Kyii'nin Myanmar'ın iç huzurunu bozduğunu Kaderr'in ise Doğu Türkistan'da 1997 yılından itibaren yürütülen terörist faaliyetlerin baş aktörü olduğu şeklinde savunmaktadırlar. Myanmar ve Çin yönetimi kendilerine göre bu şekilde haklı nedenler ileri sürerek dünya kamuoyunda kendilerini haklı çıkarmaya çalışmaktadırlar. Bunu yaparken de bazı uluslararası güçlerden destek almaktadırlar. Örneğin 11 Eylül 2001'de ABD'de ikiz kulelere yapılan saldırlar sonrası, ABD Başkanı George W Bush'un terörizme karşı tüm dünya devletleriyle birlikte mücadele kararını alması, dünya kamuoyunda terörist faaliyetlerle mücadelede yeni bir dönemi başlatmış oldu. ${ }^{5} \mathrm{Bu}$ noktadan hareketle Pekin yönetimi, ufak çaplı eylemlerin yaşandığı Doğu Türkistan'daki eylemleri, El Kaide bağlantılı göstermeye çalışarak, Doğu Türkistan'daki despot iradesini meşrulaştırma arayışı içine girişmiştir. Böylece gerek ABD gerekse AB nezdinde, Doğu Türkistan'daki hak arayışı faaliyetleri; Çin, $\mathrm{ABD}$ ve $\mathrm{AB}$ üçgeninde terörist eylemler olarak gösterilmeye başlandı. Ne var ki; ne Kaderr'e ne de Kyii’ye yöneltilen bu suçlamaların doğruluk payı taşıdığı söylenemez. Bu bağlamda çalışmada, Myanmar ve Doğu Türkistan’ın siyasi yapısının kısa bir incelemesi yapılacak ve Kyii ile Kaderr’in siyasetteki süreçleri açıklığa

ve Sorunları", Oluslararası Ilişkiler Dergisi, Cilt 7, Sayı 26, 2010, s, 3.

4- Jiyoung Song, “The Challenge for Asia's Female Politicians”, The Diplomat, 2016, s, 1-3.

5-Shirley, A. Kan, “U.S.-China Counter Terrorism Cooperation: Issues for U.S. Policy”,Congressional Research Service, 2010, s, 1 . 
kavuşturulacaktır. Böylece, dünya kamuoyunda birey aktör konumundan ileri gidemeyen iki kadın siyasetçinin bugünkü siyasi konumları Çin, Myanmar ve Batı üçgeninde açıklanmaya çalışılacaktır.

\section{KADIN SORUNUNA GENEL BİR BAKIȘ: DÜNYADA VE ASYA TOLUMUNDA KADIN SIYYASAL FIGÜRLER}

Dünyanın diğer bölgelerinde olduğu gibi, Asya kıtasında da kadın siyasetçilerin siyasi durumu bir belirsizlik içindedir. Dünya nüfusunun yaklaşık olarak yarısını oluşturan kadınların büyük bir çoğunluğu sadece seçme yükümlülügünü üstlenmektedirler. Hal bu ki hükümetlerin kurulmasında seçmen olarak önemli bir paya sahip olan kadınlar aynı önemi seçilme sürecinde görememektedirler. ${ }^{6}$ He fırsatta kadın haklarını savunan siyasiler konu kadınların seçilmesine gelince sessiz kalmaktadırlar.

Kadınlar demokratik ortamların yapı taşıdır. Kadınların politik katılımı ve toplumsal cinsiyet eşitliği gerçek demokrasinin yaşam bulmuş halidir. Neredeyse tüm dünyada devletler demokrasi ile yönetilmektedir. Ancak demokrasi ile yönetilen devletler de dahil olmak üzere, demokratik oluşumun şartları bir bütünlük içinde uygulanmamaktadır. Demokratik sistemlerde cinsiyet ayrımcılığı olmamalıdır. Tüm kesimlerin bir arada yaşadığ 1 , yasalar önünde herkesin eşit olduğu ve herkesin her işi yapabildiği ortamlarda gerçek demokrasilerden bahsedebiliriz. Her ne kadar yasalar önünde herkesin eşit olduğu bir dünyada yaşanılıyor olsa da, bu durum işleyiş açısından farklılıklar taşımaktadır. En gelişmiş Avrupa ülkelerinde dahi cinsiyet ayrımcılığ görülmektedir. Dolayısıyla evrensel bir demokratik oluşumdan bahsedemeyiz.

Kadın sorununun çözümü için kadınlara karşılık politik sorumluluk, karar alma pozisyonlarında kadın sayısının artırmakla başlar. Cinsiyet eşitsizliği bir sorundur ve bu sorunun çözümü konusunda pek çok çalışma yapılmıştır. Ancak şu an için bu sorun çözüme kavuşmuş değildir. Zira kadınlar karar alma pozisyonlarında ciddiyetle temsil edilmemekte ve seçkin kadrolar siyasi kadın figürlere yönelik siyasi baskılarını devam ettirmektedir. Bu nedenle kadınların siyasette az temsil edilmesi sebebiyle kadın haklarının savunuculuğunu yapmak, dünya çapında demokratikleşme için bir meydan okumadır.

Kadınların siyasi temsil hakkı 20. Yy ortalarında görülmeye başlanmıştır. Aynı şekilde, kadınların eğitim seviyeleri ve istihdam oranının 20. Yy ortalarında yukarı eğilimli bir artış göstermesi, demokratik kalkınmanın itici bir gücü olarak kabul edilmiştir. Bu yüzyıldan itibaren kadınlara seçme ve seçilme hakkı tanıyan ülke sayında artış olsa da, özelikle seçilme hakkı sadece yasalarda var olmuştur. Demokratik sistemlerde kadınlara daha fazla fırsat eşitliği sağlandığı iddiasının gerçekleri yansıtmadı̆̆ı bu yüzyılda, kadınların siyasi katılım oranın çok az olduğu bilinmektedir. Kadınlar ülke ekonomilerinin kalkınmasının

6- Kazuki Iwanaga, "Women's Political Participation and Representation in Asia” Nordic Institute of Asian Studies, 2008, s, 1. 
bir parçası olabilirken az sayıda kadının aktif siyaset yaptığı bu yüzyılda, kadınların temsil sorunu dünya genelinde önemli bir sorun haline dönüşmüştür.

Parlamentolar, özellikle toplumun tüm bireylerinin bir arada oluşturulduğu bir yer olmasına karşın neredeyse tüm dünyada parlamentolara egemen olan güç erkekler olmuştur. ${ }^{7} \mathrm{Bu}$ anlayışın yavaş yavaş değişime uğradığı 21.Yy'de pek çok ülke kadınların siyasal temsil oranının arttırılması için kota politikaları geliştirmiştir. Geliştirilen bu kota politikaları sonucunda kadın siyasetçilerin sayısı dünya genelinde artış göstermeye başlamıştır. Örneğin Dünya genelinde kadınların siyasetteki temsil oranı, 1995'te \%11 iken bu oran 2015 'te \% 22'ye çıkmıştır. Asya kıtasında ise kadınların siyasete katılma oranı \% 16 seviyesindedir. ${ }^{8}$ Dünya genelinde günümüze kadar 70 kadın Cumhurbaşkanı ve Başbakan olarak görev yapmıştır. Şu an için dünya genelinde kadın Cumhurbaşkanı veya Başbakan olarak görev yapan kadınların sayısı, 2019 yılı itibariyle 15'dir. 9'u Avrupa, 4'ü Asya ve 2'si Afrika kıtasındadır. Bu rakamlar Birleşmiş Milletler'e üye 193 devletin $\% 10$ 'undan daha azını temsil etmektedir.'

Kadın sorunuyla ilgili ülkeveya kıta ayrımı yapmakkadın sorununu anlamsızlaştırmaktadır. Ancak Batılı ülkelerin aksine Asya kıtasında kadın sorunu daha dikkat çekmektedir. Asya kıtasında kadınların sosyoekonomik durumu ve biçimsel siyasal hakları son yıllarda önemli ölçüde gelişme göstermesine rağmen Asyalı kadınlar; siyasal kurumlarda, özellikle ulusal meclislerde ve yerel yönetimlerde yeterince temsil edilmemektedir. Zira Asya kıtasının demografik yapısı göz önüne alındığında kadının siyasette temsil oranı çok düşük kalmaktadır.

Asyalı kadınlar seçme ve seçilme hakkını gelişmiş Avrupa ülkelerinden sonra kazanmıştır. Sadece üç Asya ülkesi 2. Dünya savaşından önce kadınlara seçme hakkı tanımıştır. Kadınlara ilk seçme hakkı tanıyan Asya ülkesi (1931) Sri Lanka'dır. Diğer ülkeler ise, (1932) Tayland ve (1935) Myanmar'dır. ${ }^{10}$

Asya toplumunda kadınlara biçilen görevler arasında daha çok anne olmak ve ev işleriyle ilgilenmek olsa da Asya kıtasında kadın siyasetçilerin sayısı her geçen gün artmaktadır. Ancak ülke yönetimlerinde yer almaları için zor seçimlerden geçmeleri gerekmektedir. Erkeğin egemen olduğu bir toplumda kadın siyasetçilerin erkek siyasetçilerle seçim yarışmasına girmesi daha zor olacaktır. Ancak Asyalı kadın siyasetçilerin eğitim sevilerinin ve ekonomik güçlerinin artmasıyla dayatılan engeller aşılarak siyasette daha aktif roller üstlenilmeye başlanmıştır. Asyalı kadın siyasetçileri ülkelerinde bir değişimin habercisi olarak görmek şu an için olumsuz olarak görülmektedir. Zira Asya toplumunda kadın

\footnotetext{
7- Ben Hillman, "Increasing Women's Parliamentary Representation in Asia and the Pacific: The Indonesian Experience", Asia \& the Pacific Policy Studies, 2017, s, 1-3.

8- Women in Parliament: 20 years in review, Inter-Parliamentary Union, http://archive.ipu.org/pdf/publications/ WIP20Y-en.pdf, erişim tarihi:10.07.2018

9- Abigail Geiger, Number of Women Leaders Around the World has Grown, But They're Still a Small Group, Pew Research Center, 2017, s, 5.

10- Kazuki Iwanaga, a, g, e, s, 1.
} 
siyasetçiler, Batı ülkelerindeki hem cinsleri gibi siyasette aktif rol üstlenmemektedirler. Asya toplumundaki kadın siyasetçiler; babalarının, eşlerinin ya da politik aile bağlarının verdiği imkânları kullanarak siyasetin içinde olmuşlardır. Örneğin; Sheikh Hasina Wajed, Benazir Bhutto İndira Priyadarşini Gandhi, Gloria Macapagal-Arroyo (Filipinler), Megawati Sukarnoputri (Endonezya) ve diğer bazı Asyalı kadın liderler aile bağlarını kullanarak siyaset yapmışlardır. ${ }^{11}$ Asyalı kadın liderlerin siyasetin içinden gelmeyişi liderlik vasıflarını güçsüz kılmaktadır.

Dünya genelinde siyasetteki kadın sayısının artış hızının yavaş olduğu göze alındığında, siyasetteki kadın erkek dengesizliğine çözüm bulmak için çoğu devlet kota sistemi geliştirmiştir. Kota sistemi kadınların siyasete doğrudan girmesini sağlamaktadır. Böylelikle kadınların seçilmesi daha kolay olacak ve seçilen kadın sayısında bir artış sağlanacaktır. ${ }^{12}$ Kota sistemi bir bakıma kadınlar açısından lehte sonuçlar doğurabildiği gibi bazı durumlarda da aleyhte sonuçlar doğurabilmektedir. Bu tezatlık kota sisteminin içeriğiyle ilgilidir. Zira kota sisteminin iki farklı yönü vardır. İlki devletlerin anayasasında güvence altına alınan kota sistemidir. Bu sisteme göre; seçilecek kişiler arasından belli bir kota belirlenerek kadınların seçilmesi amaçlanmaktadır. Bu sistem doğrudan kadının temsil edilmesini sağlamaktadır.

İkincisi ise partilerin gönüllük esasına dayalı olan kota sistemidir. Bu sisteme göre; partiler, kadın aday belirlemek veya belirlememek konusunda özgürdürler. Partilere dışarıdan baskı yapılamaz. Partiler seçim bölgelerinin oy potansiyeline göre kadın aday belirleyebilir. İki farklı kota sisteminden anlaşılacağı üzere; devlet anayasaları altında olan kota sistemleri kadınların seçilmesini kolaylaştırırken, partilerin belirlediği kota sistemi, kadınların seçilmesini zorlaştırmaktadır.

Kota sitemi neredeyse tüm dünyada uygulanmaktadır. Ancak uygulanış açısından bölgelere göre farklılıklar taşımaktadır. Asya kıtasında uygulanan her iki kota sistemi kadınların aleyhinde olmaktadır. Zira Asya kıtasında devlet güvencesi altında olan kota sistemi kadınların kota oranını düşük tutmaktadır. Asya’nın en gelişmiş ülkesi olan Japonya dahil diğer Asyalı devletler kadınların aktif siyasal hayata katılmasını uyguladıkları kota sistemiyle engellemektedirler. Dolayısıyla Asyalı kadınlar, niteliksel ve niceliksel olarak siyasette etkisiz hale gelmekte ve az temsil edilmektedir. Tüm bu engellere rağmen Asyalı kadın aktörlerin sayısında kısmi bir artış görülmektedir.

Asyalı kadın siyasetçilerin bu başarılarına rağmen istenilen sistem değişikliğine ulaşılmış değildir. Ancak Asyalı kadınların sistemin bir paçası olması yolunda başlattığı bu mücadele kadınların bilinçlenmesini hızlandırmış ve siyasette yeni kadın liderlerin çıkmasına zemin hazırlamıştır. Asya toplumunda sistemin bir parçası olmak isteyen kadınlar, sadece siyaset yapmamalıdırlar. Kadınlar siyasi kimliklerinin dışında bürokratik çalışmaların içinde olmalıdırlar, sivil toplum kuruluşlarının tepe noktalarında görev

11- Szczepanski, Kallie, "Female Heads of State in Asia." ThoughtCo, 2018, s, 1-4.

12- Kazuki Iwanaga, a, g, e, s, 10. 
almalıdırlar, kadınlar arası dayanışmayı güçlendirmelidirler, kadın siyasetçiler kadınların sesi olmalıdırlar ve siyasetin sadece erkelerin yapabileceği bir iş olmadığını siyasette aktif rol üstelenerek göstermelidirler. Başlatılan bu mücadele sonrası pek çok alanda kadın varlığı erkekler tarafından hissedilmiş olunacaktır. Böylelikle Asya kıtasında bir sistem değişliği yaşanabilir. Şu an için ülkelerinin yönetiminde olan Asyalı kadınlar; Tsai Ingwen Tayvan Cumhurbaşkanı, Şeyh Hasina Bangladeş Başbakanı, Bidhya Devi Bhandari, Nepal Cumhurbaşkanı ve Myanmar’n Defacto lideri Aung San Suu Kyii, görevlerini yürütmektedir. ${ }^{13}$ Asya siyasetinde aktif görev yapan kadın liderler arasında en dikkat çekici olanı Kyii'dir. Kyii, askeri rejimin tüm engellemelerine rağmen ülkenin lideri olmayı başarmıştır. Yarım asrı geçen süredir askeri rejim tarafından yönetilen Myanmar’ı demokratik sistemle buluşturması Kyii'nin başarısının bir göstergesidir. Kyii’nin askeri yönetime karşı elde ettiği başarı diğer Asyalı kadın siyasetçilere örnek olmalıdır.

\section{MYANMAR'IN SIYYASAL SÜRECİ VE DEMOKRASIYYE GEÇİS DENEMELERİ}

Myanmar’n siyasal yapısının tarihsel bir incelemesi yapıldığında, ülkeyi yöneten siyasi liderler ile halk arasında, siyasi nedenlere bağlı olarak bir iletişim eksikliği olduğunu bugün de görmek mümkündür. Siyasi liderler (askeri liderler) ve halk arasında yaşanan bu iletişim eksikliği, dünyadaki en uzun iç çatışmaların birisinin bu coğrafyada yaşanmasına neden olmuştur. Ülke genelinde yaşanan içi çatışmalar devam ederken, 1824'te İngiliz Hindistanının toprağına saldırılması; Myanmar’n İngiliz sömürgesi olmasına yol açmıştır. Bu yaşanan gelişme Myanmar’ı siyasi, iktisadi ve askeri bakımdan yoksun bir ülke yaparken var olan iç sorunlarına bir yenisi daha eklenerek Myanmar halkı için yeni bir siyasal süreç başlamıştır. ${ }^{14}$ İngiliz sömürge sistemine karşı başlatılan ayaklanmalar Myanmar’n 1948'de tarih sahnesine bağımsız bir devlet olarak çıkmasını sağlamıştır. $\mathrm{Ne}$ var ki Myanmar halkı bağımsızlık sevincini yaşayamadan sömürge öncesi dönemden kalan sorunlar tekrar gündeme gelmiştir ve kurucu lideri Aung San suikast sonucu öldürülmüştür. ${ }^{15}$

Kurucu lider Aung San’ın öldürülmesiyle ülke yönetiminin yeni lideri U Nu, Myanmar’ı Myanmar Krallı̆̆ı dönemindeki gibi yönetmeye, yani Myanmarlıların diğer gruplar üzerindeki baskıcı yapısını devam ettirmeye başladı. Böylece ülke genelinde bağımsızlık sonrası ilk isyanlar başlamış oldu. ${ }^{16} \mathrm{U} \mathrm{Nu}$ hükümetine göre; Myanmar tek bir çatı altında toplandığı takdirde esas bağımsızlığını kazanmış olacaktır. Zira etnik grupların özelliklerine baktığımızda her biri yüzyıllar öncesinde Myanmar’a farklı ülkelerden (Çin, Hindistan ve Tayland) göç ettiğinden Myanmar bu ülkelerin dillerinin, kültürlerinin ve en önemlisi dinlerinin etkisi altındaydı. Bu nedenlerden dolayı Myanmar federal bir yapıya

\footnotetext{
13- Abigail Geiger, a, g, e, s, 5.

14-History of Burma, From a Multi-Ethnic Perspective, The Curriculum Project, Thailand, 2005, s, 24.

15-Chizom, Ekeh, "Minorities in Burma", Minority Rights Group International, England, 2007, s, 1.

16-Sakhong, H. Lian, "The Dynamics of Sixty Years of Ethnic Armed Conflict in Burma” Burma Center for Ethnic Studies Peace and Reconciliation, Analysis Paper No.1, 2012, s, 4.
} 
bölündüğünde Çin, Hindistan ve Tayland'ın azınlıkların bu özelliklerinden yararlanarak azınlıkları kendi çıkarları doğrultusunda kullanabileceği ihtimali vardı.(ki soğuk savaş döneminde azınlıklar ile merkez hükümet arasında iç çatışmaların çıkmasına neden olmuşlardır). Bu nedenle U Nu, Myanmar’ı Üniter devlet modeli ile yönetmek istemiştir. ${ }^{17}$ U Nu’nun bu düşüncesi iç isyanların çıkmasına neden olmuştur. Ülke genelinde yaşanan isyanlar ve iç çatışmaları bastıramayan U Nu yönetimi, 1962 'de General Ne Win tarafından yönetilen darbe sonucu devrilmiştir. ${ }^{18}$

Ordunun ülke yönetimine el koyması her ülkede olduğu gibi Myanmar'da da demokrasiye vurulan en büyük darbe olmuştur. Ülkenin 2010 yılına kadar katı kurallarla yönetilmesi; adalet sisteminin, özgürlüklerin ve siyasal hayatın çökmesine neden olmuştur. Halkın özgürlük, eşitlik ve demokratik hak arayış mücadelesi ülke geneline yayılınca askeri yönetim halk mücadelesini bastırmak için orantısız güç kullanmıştır. Çıkan çatışmalarda özgürlük mücadelesi veren çok sayıda kişi öldürülmüştür. Bu yaşanan gelişme $\mathrm{ABD}$, Batı ve bölge ülkelerinin tepkisine neden olmuştur. $A B D$, Batı ve bölge ülkeleri askeri yönetiminin bir an önce ülke yönetimini sivillere bırakılması uyarısında bulunmuşlardır. Askeri yönetim tüm uyarılara rağmen otoritesini korumak için halkı baskı altına aldı ve ülkenin yönetimini baskıcı politikalarla yönetmeye devam etmiştir. $A B D$ ve Batı karşısında oldukça güçsüz bir konumda olan askeri yönetimin bu kararları alırken en büyük destekçisi Çin olmuştur. Zira stratejik nedenlerden dolayı Myanmar askeri yönetimini desteklememiştir.

Çin'in Myanmar askeri yönetimini desteklemesinin iki nedeni vardır. Myanmar her ne kadar ekonomik olarak çok güçsüz bir ülke olsa da enerji kaynakları bakamından zengin bir ülkedir. Dünyanın en fazla enerji tüketen ülkesi Çin, Myanmar’ın enerji kaynaklarının peşindedir ve bundan dolayı Myanmar askeri yönetimini desteklemektedir. İkinci neden ise Myanmar’ı Hint Okyanusu’na çıkış kapısı olarak görmesidir. Çin’in Malakka Boğazı dışında Hint Okyanusu'na ulaşabilmesinin tek yolu Myanmar'dır. Myanmar ile yakın ilişkiler kurup kendisine alternatif bir ulaşım yolu bulmuştur. Böylece Myanmar, Çin’in hem enerji güvenliğinin bir parçası olacak hem de ulaşım hatları üzerinde yaşanabilecek bir anlaşmazlığ engellemiş olacaktır.

Çin, askeri yönetimi destekledikçe askeri yönetim halk üzerindeki baskısını arttırdı, ülkedeki gücünü korudu ve $\mathrm{ABD}$, Batı ve bölge ülkelerine karşı bir denge sistemi kurdu. Zira Çin yaptırımlar karşısında askeri yönetime ekonomik yardım ve iç isyanların bastırılması için de silah yardımında bulunmuştur. Bu nedenlerden dolayı Çin-Myanmar ilişkisi karşılıklı çıkara dayanmaktadır. Öte yandan Çin’in ve Myanmarın birbirlerini desteklemesi ABD, Batı ve bölge ülkelerinin Asya’daki çıkarlarını tehlikeye sokmuştur. Myanmar'ı Çin hegemonyasından kurtarmak için Myanmar'daki demokrasi harekatını desteklemişlerdir. Geliştirilen baskı politikaları sonucunda 2015 yılındaki seçimde sivil partilerin de yönetime katılmasıyla bir nebze demokrasi adına olumlu gelişmeler atılmıştır.

17- Sakhong, H. Lian, a, g, e, s, 5.

18-Johari, Zaiton, The Role of the Tatmadaw in Modern Day Burma: An Analysis, Naval Postgraduate School, California, 2000, s, 48 . 
Ancak askeri yönetimin ülke yönetimi üzerinde söz hakkı hala devam etmektedir.

\subsection{Aung San Suu Kyii: Demokrasi Mücadelesi, Karşılaştığı Zorluklar ve Liderlik Başarısı}

Aung San Suu Kyii’nin Myanmar halkı tarafından "Myanmar Demokrasi Harekatı” lideri olarak tanımlanmasının iki nedeni vardır. Ülkenin kurucu lideri General Aung San’ın kızı olması ve askeri rejiminin despot idaresine karşı demokrasi hareketini savunmasıdır. Bu iki neden Kyii’nin Myanmar’ın ikinci kurucu lideri vasfını taşımasına neden olmuştur. Ne var ki; Kyii’nin demokrasi adına başlattığı mücadele birbiri ardına yaşanan darbeler nedeniyle çok uzun sürmemiştir.

Darbeler ülkesi olarak nitelendirebileceğimiz Myanmar'da yaşanan darbelerde generallerin ortak ve tek amacı, devlet düzenini sağlamak, ekonomik durumu iyileştirmek, çok partili sisteme geçmek ve dikta rejimini sonlandırarak demokrasiye geçmek olmuştur. Ne var ki, her darbe döneminde bu amaçlar hep göstermelik kalmış, siyasi ve ekonomik problemler yaşanmıştır. Örneğin en son yaşanan 1988 darbesinden kısa bir süre sonra askeri yönetim devlet yönetiminin sivillere bırakılacağı sözünü vermiştir. ${ }^{19}$ Ayrıca halkın partiler ve örgütler kurabilmelerinin yolunu açan çok partili genel seçim kanunu ve siyasal partiler sicil kanununu da onaylamıştır. ${ }^{20}$

Askeri yönetim tarafından böylesine bir radikal kararın alınması hiç şüphesiz Myanmar’ın demokrasi tarihindeki en önemli gelişmelerden biri olmuştur. Böylelikle hem Myanmar’ın küresel boyuttaki kötü imajı düzeltilecek hem de yapılacak serbest seçimler sayesinde çok partili demokrasi sürecine geçilmiş olunacaktı. Yeni seçim kanunu ile birlikte yeni partilerin kurulmasıyla seçim hazırlıklarına başlanılmıştır. Yapılan seçim çalışmalarında askeri yönetimin en önemli rakibi Kyii olmuştur. Kyii, propaganda sürecinde halka Budist fikirlerin ve demokrasinin cunta sistemi altında gelişmeyeceğini anlattı. Uzun yıllar boyunca askeri yönetimlerin katı kurallarına maruz kalan halk, kendilerine ve düşüncelerine hitap eden Kyii'yi ciddi anlamda desteklemeye başladı. Kyii'nin halk tarafından bu denli bir destek görmesi, askeri yönetim tarafında bir şok etkisi yarattı. Halkın sempatisini kazanan ve Myanmar'ın yeni lideri olmaya çok yakın olduğu bu dönemde serbest seçimler yapılmadan önce askeri yönetim tarafından Kyii, 1989'da, 6 yıl boyunca ev hapsinde tutuldu. ${ }^{21}$ Kyii'nin ev hapsinde tutulması ülke halkının askeri yönetime karşı daha çok tepki göstermesine neden oldu. Zira ülke yönetimine aday olan bir liderin ilk defa demokrasi, özgürlük ve eşitlik gibi kavramlarını propaganda sürecinde kullanması halk tarafında büyük bir sevinç yaratmıştır. Myanmar'in demokratik geleceğinin Kyii’nin politik düşüncelerinde gören halk, 1990 seçiminde Kyii’nin partisini desteklemiştir.

19-Konsam Shakila Devi, Myanmar under the Military Rule 1962-1988, International Research Journal of Social Sciences Vol. 3, 2014, s, 48.

20-"Burma the 18 September 1988 Military Take over and Its Aftermath”, Amnesty International, 1988, s, 3. http://www.ibiblio.org/obl/docs3/18_Sept_1988-ocr.pdf, erişim tarihi:15.07.2018.

21 - David I. Steinberg, “Aung San Suu Kyi and U.S. Policy toward Burma/Myanmar”, Journal of Current Southeast Asian Affairs, 2010, s, 38. 
Kyii’nin partisi tüm oyların \% 82 'sini alarak 485 sandalyeden 395'ini kazanıp birinci parti olmuştur. ${ }^{22}$

Sonuçların açıklanmasıyla hem Myanmar'da hem de dünya kamuoyunda Asya’nın ikinci kapalı ülkesinde demokratik seçimlerin yapılması ve sonuçlar büyük bir sevinç yaratmıştır. Aynı zamanda seçim sonuçları tüm kesimlerce Myanmar’ın ikinci bağımsızlığı olarak algılanmıştır. Ancak bir kesim tarafından zafer olarak algılanan bu durum diğer kesim tarafında bir yenilgiden başka bir şey değildi. Askeri yönetim tarafından Kyii’nin tutuklu olmasına rağmen partisinin seçimlerden galip çıkması açıklanacak bir durum değildi. $\mathrm{Bu}$, askeri yönetim tarafından açıklaması güç bir durum olsa da temelde anlamak hiç zor bir durum değildir. Çünkü Myanmar’ın bağımsızlığından itibaren halkın istekleri göz önünde bulundurulmadan yönetilmesi ve askeri elitlerin her alanda söz sahibi olması sadece kaçınılmaz olanı geciktirmiştir. Sonuç olarak bu seçimde kısa bir süreliğine kazanan kesim demokrasi yanlıları olmuştur.

Seçim sonunda güç kaybeden askeri yönetim, bu seçim sonucunu iptal ederek yeni bir hükümetin kurulmasına izin vermedi ve ülkeyi askeri kurallarla yönetmeye devam etti. Halk ise hükümete karşı tekrar ayaklandı. İsyanları bastırmakta zorlanan askeri yönetim demokrasiye geçişin sağlanması için yeni bir anayasa hazırlamaya karar verdi. Askeri yönetimin demokrasi sürecinin hızlanması için başlattığı bu adım dünyanın Myanmar’a bakış açısını değiştirmedi. Birleşmiş Milletler Yüksek Komiserliği ve Birleşmiş Milletler Genel Sekreterliği; Myanmar’da yaşanan çatışmalar nedeniyle, askeri yönetimi kınama kararı aldılar. Demokrasinin önündeki engelleri kaldırmayan askeri yönetim, hem iç sorunları ile uğraşırken hem de ABD ve Avrupa devletlerinin yaptırımlarına maruz kalmaktaydı. Bir an olsun bu sorunların üstesinden gelebilmek için yaptırımların başlatılmasına neden olan demokrasi hareketi lideri Kyii'yi, 1995 yılında serbest bıraktı. Kyii serbest kalmasıyla birlikte daha önceki propaganda sürecinde olduğu gibi demokrasi ile ilgili düşüncelerini halka anlatmaya başladı. Düşüncelerini daha geniş kitlelere ulaştırabilmek için 2000 yılında parti yöneticileriyle birlikte mitingler düzenlemek isteyince, Kyii ikinci kez ev hapsinde tutuldu. ${ }^{23}$

Kyii’nin demokrasi için başlattığı her girişimin askeri yönetimlerce engellenmesinden dolayı, BM Güvenlik Konseyi, askeri hükümetin hem Myanmar'ın hem de bölgenin güvenliğini tehlikeye attığını gerekçe göstererek, 12 Ocak 2007'de askeri hükümete yaptırım kararı almak istedi. Ancak Çin ve Rusya Myanmar'ın bölgenin güvenliğini tehlikeye sokmadığını ve askeri hükümetin de demokrasiyi kısıtlamadığını gerekçe göstererek, BM yaptırım kararını veto ederek askeri yönetimin yanında yer aldı. ${ }^{24}$ Askeri yönetim her ne kadar Çin ve Rusya’nın destekleriyle yaptırım kararları engellenmiş olsa da

22-“US Department of State Self Study Guide for Burma”, United States Department of State Washington, D.C. 2010, s, 18.

23- Myanmar's Suu Kyi - from housewife to democracy hero https://www.reuters.com/article/idINIndia-52870120101112 erişim tarihi:13.08.2018.

24- Robert Sutter, "Myanmar in Contemporary Chinese Foreign Policy - Strengthening Common Ground, Managing Differences”, Journal of Current Southeast Asian Affairs, 2012, s, 44. 
Kyii askeri yönetim için hala yeni yaptırımların tetikleyicisi olarak görülmekteydi.

Askeri yönetim Kyii sorununu çözmek ve ABD ve Batılı devletlerin yeni yaptırım kararlarına maruz kalmamak ve adil seçimlerin yapılması için yeni bir anayasa hazırlama kararı aldı. Hazırlanan bu yeni anayasa içerik bakımdan demokrasiye geçişin bir adımı olarak algılanacak ancak askeri yönetimin en önemli rakibi Kyii siyasette pasif kalacaktır. Zira bu anayasaya göre; Myanmar devlet başkanı olabilmenin yolları bu anayasada belirtilmiştir. 2008 anayasasına göre; Myanmar devlet başkanı olmak için Myanmar vatandaşı olmak ilk şarttır. Ancak bu anayasanın diğer maddelerine göre; Myanmar devlet başkanı olmak isteyen kişinin yabancı biri ile evli olmaması gerekmektedir.

Kyii, eşinin ve çocuklarının yabancı uyruklu (İngiliz vatandaşı) olması nedeniyle devlet başkanı olamayacaktır. Her devletin kendi anayasasında devlet Başkanı olabilmenin şartlarını belirleme hakkı mevcuttur. Sonuç olarak askeri yönetimin devlet başkanı olabilmenin yolarının anayasada belirtmiş olması bir sorun olmayacaktır. Böylece askeri yönetim, Kyii’nin devlet Başkanı olmasının yolunu kapatmıştır. Kyii, askeri yönetimin tüm engellemelerine rağmen 2011 genel seçiminde 48 sandalye kazanarak askeri yönetimle birlikte hükümet kurmuştur. Bu durum ülke genelinde (Müslümanlar hariç) dikta rejimden demokrasiye geçiş olarak algılandı. Öte yandan askeri yönetimin parlamentoya sivillerin girmesinin yolunu açması, ABD tarafından da demokrasiye geçiş sürecinde önemli bir adım atılmış olarak algılandı. ABD, 2011 seçiminde Kyii’nin de ülke yönetiminde yer almasıyla Myanmar ile olan ilişkilerini yumuşatmaya başladı ve ilk olarak ekonomik yaptırımları durdurdu. ABD ve Myanmar arasında olumlu gelişmelerin yaşandığ 2012 yılında karşılıklı olarak iki ülkede büyükelçilikler açıldı. ABD’nin desteğiyle, 2014 yılında Myanmar’a ASEAN başkanlığı verildi. ${ }^{25}$

Myanmar tarihinde yaşanan bu olumlu gelişmelerin yenileri, ülke tarihinde ilk kez bağımsız bir seçim yaşanması ve ülke yönetiminin sivillere bırakılmasıyla devam etti. 2015 seçiminden Kyii’nin partisi zaferle çıkarak ülkenin ilk sivil hükümetini kurdu. Ancak 2008 anayasası gereği Kyii devlet başkanı olamadı. Ülke yönetimine Kyii’nin yakın arkadaşı Htin Kyaw geçerek Myanmar'ın ilk sivil başkanı oldu. Sonuç olarak Myanmar, bağımsızlık döneminde 2015 yılına kadar geçen süre içinde; sömürge yönetiminden bağımsızlı̆̆a, parlamenter demokrasiden askeri diktatörlüğe ve son olarak diktatörlükten sivil yönetime geçiş aşamalarından geçmiştir. Ülkede demokrasinin kurulması için uzun yıllar mücadele veren Kyii, bu geçiş sürecinin mimarıdır.

\subsection{Arkan Krizi: Aung San Suu Kyii ve Askeri Yönetimin Rolï}

Uzun yıllar boyunca Myanmar'da Budistlerin Müslüman azınlık Rohingyalılara uyguladıkları şiddet politikaları, 28 Mayıs 2012'de Ramri kentinde Budist bir rahibenin, üç Rohingyalı Müslüman genç tarafından tecavüz edildikten sonra öldürülmesi iddialarıyla

25- Yun, Sun, Myanmar's ASEAN Chairmanship, Stimson Center, Great Powers and the Changing Myanmar Issue Brief No. 4 September 2014,s, 4. 
bir kez daha gün yüzüne çıktı. ${ }^{26}$ Budistler, 3 Haziran 2012'de Rohingyalı Müslümanların bulunduğu otobüse saldırı düzenleyip 10 kişiyi linç ettiler. Ayrıca Budistler, 8 Haziran'da halkı isyana sürükleyerek, Moungdaw'da Müslümanların köylerine, evlerine ve işyerlerine saldırdılar. ${ }^{27} \mathrm{Bu}$ saldırılar karşısında hükümetin sessiz kalması ve olayların bastırılması için sadece sokağa çıkma yasağını uygulaması uluslararası toplumun tepkisine neden olurken aynı zamanda da bu katliam dünya gündeminin önemli olayları arasında BudistMüslüman çatışması olarak yerini aldı.

Müslümanlara yapılan baskılar sonucu yine yüz binlerce Arakanlı Müslüman komşu Bangladeş'e mülteci olarak göç etmek zorunda kald. Ancak Bangladeşli yöneticiler, Bangladeş’in gerek yüz ölçümünün küçük olması gerekse nüfusunun oldukça çok olması ve aynı zamanda da ekonomik olarak güçsüz bir ülke olması nedeniyle, daha fazla mültecinin ülkelerine gelmesine izin vermekte çekinceli davrandılar. ${ }^{28}$ Müslümanlara yönelik hükümetin ve Budistlerin bu sert tutumu böyle devam ederken, 2016 y1lindaki şiddet olaylarında merkezi hükümet ve Kyii’nin Müslümanlara yönelik tutumu uluslararası kamuoyunda büyük tepkilere neden oldu. Birleşmiş Milletler ve İslam İşbirliği Teşkilatı gibi kuruluşlar Arakan'daki olayları Müslümanlara yönelik etnik bir temizlik olarak tanımlamıştır ve bir an önce Müslümanların maruz kaldığı olayların sonlandırılması için bazı kararlar almıştır. ${ }^{29}$ Alınan bu kararlar; iç göçe zorlanan insanların tutulduğu kampların kapatılması, ordu tarafından oransız güç kullanılmaması, Müslümanların yerel yönetimlerde temsil hakkının sağlanması ve yardım görevlilerinin Arakan bölgesine serbestçe girmesine izin verilmesi şeklindedir. Ayrıca Müslümanlara yönelik katliam, toplu tecavüz, adam kaçırma, yağma ve insanlığa karşı her suçun son bulması gerektiğini belirten rapor, Kyii'nin de içinde bulunduğu hükümete sunulmuştur. Ancak merkezi yönetim bu kuruluşların aldıkları kararları ve taleplerini kendi iç sorunu olduğunu ileri sürerek reddetmiştir. Burada sorulması gereken bir başka soru ise; bu uluslararası örgütlerin Arakan sorununa neden çözüm bulamadığıdır. Arakan sorununa çözüm üretilememesinin her bir örgüt açısından farklı nedenleri vardır.

Örneğin BM açısından Arakan sorununu ele alırsak, örgütün işleyişi buna izin vermemektedir. Birleşmiş Milletler Güvenlik Konseyi Arakan sorunu ile ilgili alacağ 1 yaptırım kararı örgütün daimi üyeleri olan Çin ve Rusya tarafından veto edilmektedir. Dolaysıyla örgüt kınama kararı almaktan öteye gidememektedir. Bunun bilincinde olan Myanmar hükümeti ve Budistler, hedefleri doğrultusunda Müslümanları sınırlarından atmaya çalışmaktadır. Arakan sorununa İİT açısından bakacak olursak, bu örgütler arasında en zayıf halkayı oluşturmaktadır. Örgüt kendi içinde bir bütünlüğe sahip değildir.

26-Laura Steckman, Myanmar at the Crossroads: the Shadow of Jihadist Extremism, International Centre for Political Violence and Terrorism Research, Singapore, Volume 7, Issue 4 May 2015, s, 11.

27-Burma police clash with Muslim protesters in Maung Daw, http://www.bbc.com/news/world-asia-18368556, erişim tarihi: 14.08 .2018 .

28-Bangladesh Refuses Entry to Myanmar Refugees, https://aawsat.com/english/home/article/1011261/bangladesh-refuses-accept-more-rohingya-refugees-fleeing-myanmar erişi tarihi: 16.08.2018.

29- Myanmar: UN Security Council Must Impose Arms Embargo https://www.amnesty.org/en/press-releases/2017/09/myanmar-un-security-council-must-impose-arms-embargo/ erişim tarihi:16.08.2018. 
İslam dünyasında yaşanan katliamlara ve savaşlara çözüm üretemezken, İslam dünyası adına Batı karşısında güçlü bir direnç gösteremezken Budist bir toplum içinde azınlık olan Müslümanlara çözüm üretmesi zor görünmektedir.

Ülkesinde haksızlığa uğradığı için Batı tarafından uluslararası barış ödülüne layık görülen Kyii, uluslararası örgütlerin aldığı kararları ve talepleri uygulamak yerine sesiz kalmayı tercih ederek Arakan Müslümanlarını yaşanan vahşetin ortasında bırakmaktadır. Burada sorulması gereken demokrasi mücadelesi veren hatta bunun için 20 yıldan fazla bir süre ev hapsinde tutulan bir liderin, neden Arakan sorunu ve halkı için sesiz kalmayı tercih ettiğidir. Ona göre; demokrasinin yerleşmediği bir toplumda dışlanmış bir grubun savunuculuğu yapmak Arakan sorununu daha karmaşık bir yapıya dönüştürecektir. Dolayısıyla Budist-Müslüman çatışmaları daha çok şiddetlenecek ve ülke nüfusunun çok ufak bir kısmını oluşturan Müslümanlar Budistler tarafından katliama maruz kalacaktır. ${ }^{30}$ Bundan dolayıdır ki Arakan Müslümanlarının savunuculuğunu yapmaktan çekinmiştir.

Bu açıklamalar Kyii için haklı bir neden olarak gözükse de en azından Myanmar'da demokrasi kurulması için dünya liderleri ile yaptığı görüşmelerde Arakan sorunuyla ilgili insan hakları ihlallerinden bahsedebilirdi. Kyii’nin Arakan sorunuyla ilgili düşüncesi, uluslararası basın kuruluşlarına verdiği röportajlarda çok açık bir şekilde dile getirilmektedir. Arakan Müslümanlarının gerçek Myanmar vatandaşı olmadığını, onların 1824'te İngilizler tarafından Bangladeş'ten Myanmar'a getirilen işçiler olduğunu çeşitli uluslararası basın kuruşlarında dile getirmektedir. ${ }^{31}$ Ayrıca, 1982'de çıkartılan Yeni Vatandaşlık Kanunu'na da atıfta bulunarak Arakan Müslümanlarının vatansız kişiler olduğunu söylemektedir. ${ }^{32}$ Asıl sorun ülke nüfusunun \% 90’nının Budist olduğu toplumda \% 2'lik bir kısmın Myanmar'ın en önemli stratejik bölgesinde yaşaması ve Myanmar topraklarından gönderilememesidir.

Kyii’nin de Budist olduğu göz önüne alınırsa, Arakan Müslümanları ile ilgili olumsuz düşüncelere sahip olması beklenen bir durum olabilir. Uluslararası alanda ülkesinin tanınmışlığından çok daha fazla üne sahip olan Myanmar'ın demokrasi hareketi öncüsü Kyii, tüm kesimin lideri olmak yerine, alt-üst kimlik ayrımı yaparak, Arakan Müslümanlarının etnik temizliğine göz yummaktadır. Kyii’nin devlet destekli Budistlerin Müslümanlara yönelik etnik temizlik yapmasına ilgisiz kalmasının bir başka nedeni devlet başkanı olmak istemesinden kaynaklanmaktadır. Kyii bu hedefine ulaşmak için ilk önce 2008 anayasasını değiştirmesi gerekmektedir. Zira bu anayasaya göre devlet başkanı olamayacaktır. İkinci olarak devlet başkanı olmak için Budistlerin oyuna ihtiyacı vardır. Budistler ülke nüfusunun \%90’nı oluşturmaktadır. Müslümanların destekçisi olduğu taktirde Budistlerin desteğini alamayacaktır. Dolayısıyla Müslümanlara uygulanan etnik temizliğe sesiz kalmaktadır. Sonuç olarak, Myanmar'da demokrasi kurulması için uzun

30- Why is Aung San Suu Kyi silent on the plight of the Rohingya people?

https:/www.theguardian.com/world/2015/may/19/why-is-aung-san-suu-kyi-silent-on-the-plight-of-the-rohingya-people erişim tarihi: 16.08.2018.

31-Muhammed, Yunus, .A History of Arakan: Pas tand Present, Magenta Colour, 1994, s, 78.

32-Muhammed, Yunus, a, g, e, s, 78. 
yıllar mücadele veren Nobel ödüllü Demokrasi öncüsü Kyii, kendisine göre haklı nedenler ileri sürerek uluslararası toplumun tepkisini çekmesine rağmen Arakan sorununa devlet başkanı olabilmek için sessiz kalmaktadır.

\section{TARİH BOYUNCA DOĞU TÜRKİSTAN'DA HAK VE ÖZGÜRLÜK MÜCADELESİ}

Orta Asya ve Asya devletlerine sınırı olan Türkistan, tarih sahnesinde Rusya ve Çin Halk Cumhuriyeti'nin hegemonyası altında kalan, stratejik ve doğal kaynak bakımından zengin bir bölgedir. Avrasya’nın kalbi olarak nitelendirilen Doğu Türkistan, tarih boyunca farklı zaman dilimlerinde ve farklı amaçlar gösterilerek istila edilmiştir. Çin ve Sovyetler Birliği tarafından istila edilen Türkistan, her iki devletin uyguladığ 1 asimilasyon ve sosyalist politikalar sonucu kimlik sorunlarıyla karşı karşıya kalmıştır. Birinci istila döneminde Çinli yetkililer Doğu Türkistan üzerinde nüfuz kurabilmek için Uygurların fakirleştirilmesi amacıyla değişik isimler altında vergiler aldı, Türk nüfusu azınlık haline getirmek için Çinlileri Doğu Türkistan’a yerleştirdi. ${ }^{33}$ Pekin yönetimine göre; bu politikalar sonucunda Doğu Türkistan halkı asimilasyona uğrayacak ve Çin’in bölgedeki egemen konumu güçlenmiş olacaktır. Batılıların sömürgesi olmak istemeyen ve bunun için Batılılara karşı mücadele eden Çin'in, Doğu Türkistan'ı ilhak etmesi, Çinli yetkililer açısından doğal bir durum olarak görülse de Doğu Türkistan halkı için kabul edilebilir bir durum değildir.

Çin’in I. ve II. Afyon Savaş'ları sonunda Batılı devletler karşısında yarı sömürge durumuna düşmesi ve güç kaybetmesiyle, Türklerin başlattığı isyanlar daha etkili bir hale gelmiştir ve Yakup Bey liderliğinde, Doğu Türkistan, 1865 yılında bağımsızlığını kazanmıştır. Doğu Türkistan’ın bağımsızlığını kazanmasıyla denge politikaları arayışı içinde olan Yakup Bey, bu yeni süreçte İngiltere, Rusya ve Osmanlı'dan yardım alarak Mançu İmparatorluğu karşısında bağımsızlığını sürdürmeye çalışmıştır. ${ }^{34}$

Öte yandan ülkedeki Türk beyliklerini bir çatı altında toplayarak, daha güçlü bir siyasi yapı oluşturma gayreti içinde olmuştur. Ancak İngiltere ve Rusya açısından Osmanlı'dan yardım almak ve Osmanlı ile ilişkiler geliştirmek, İngiltere ve Rusya’nın Doğu Türkistan politikalarıyla örtüşmemekteydi. Çünkü Rusya Batı Türkistan’a komşu olan Doğu Türkistan'da Osmanlı etkisi görmek istememekteydi. İngiltere ise; Hindistan'daki Müslümanların Osmanlıdan etkilenebileceği ihtimalini göz önünde bulunduruyordu. Dolayısıyla her zaman için daha güçsüz bir Doğu Türkistan’ı desteklemek taraftarıydılar. Yakup Bey’in Osmanlıdan askeri teçhizat alarak bölgede güç kazanmaya başlaması ile Rusya ve İngiltere; Doğu Türkistan’ı işgal etmek isteyen Mançu İmparatorluğuna yardımda bulundular ve Doğu Türkistan, 1876'da ikinci kez Mançu İmparatorluğu idaresi altına girmiş oldu. ${ }^{35}$

33- Kutay, R, Karaca, “Türkiye-Çin Halk Cumhuriyeti İlişkilerinde Doğu Türkistan Sorunu” Akademik Bakış, Cilt 1, Sayı 1 2007, s, 222.

34- Kutay, R Karaca, a, g, e, s, 223.

35- Kutay, R Karaca, a, g, e, s, 223. 
1759 yılından beri Türkistan’ın doğusunu kendi toprağı gibi göstermek isteyen Çin, bu hedefini, 1884'te Mançu İmparatorunun, bölgeye, "yeni toprak" anlamına gelen "Sincan" ismini vermesiyle başlamıştır. ${ }^{36}$ Doğu Türkistan’ın Çin nezdinde Sincan ismiyle anılmış ve kendine ait bir toprak parçası olarak görülmüştür. Çin bu politikasını gerçekleştirmek için Doğu Türkistan’ı işgal etmek istemiştir. Ancak işgal süreci, 1949 yılına kadar gerçekleşmemiştir. Zira Çin’de yaşanan iç karışıklıklar Doğu Türkistan’ın işgalini geciktirmiştir. Yaşanan iç karışıklar sonrası Zedong'un ülke yönetimini ele alması, Çin'de bir takım siyasi değişiklikler meydan getirdiği gibi, Doğu Türkistan'da da yeni değişikliler meydana getirmiştir. Çin'in kurulmasıyla Doğu Türkistan'ı işgal etmeye başlayan Zedong, 1955’te Doğu Türkistan Otonom Bölgesi’nin kuruluşunu ilan etmiştir. ${ }^{37}$ Böylece Doğu Türkistan fiilen Çin'in bir toprak parçası haline getirilmiştir.

Çin'in bölgeyi Çinlileştirmek istemesinin nedenleri; bölgenin zengin kaynaklara sahip olması ve bölgenin Çin için bir tampon bölge olmasıdır. Zira bölgeye Sovyetler Birliğìnin de sınırı olması Çin'in güvenlik endișesi duymasına neden olmaktadır. Bu nedenden dolayı Soğuk Savaş dönemi boyunca bölgenin Çinlileştirilmesi için Mançu İmparatorluğu dönemindeki gibi Zedong yönetimi de bölgenin kimliğini değiştirmek istemiştir. Uygulanan asimilasyon politikaları sonucu bölge halkının; dili, dini ve yaşam biçimleri değiştirilmeye çalışılmıştır. 1960'larda bölgede nükleer denemeler yapılmıştır. Nükleer denemeler sonucu yüzbinlerce Uygur Türkü öldürülmüştür. ${ }^{38}$ Yaşanan bu olaylar karşısında, uluslararası kamuoyu, Pekin yönetimine baskıcı tutumundan dolayı tepkilerini dile getirmiştir.

Ne var ki bu tepkiler Çin'in Doğu Türkistan politikasında bir yumuşama olmamıştır. Bilakis, 1991'de Soğuk Savaş’ın sona ermesiyle Doğu Türkistan dışında diğer Orta Asya devletleri bağımsızlığın kazanırken Çin Doğu Türkistan üzerinde etkisini daha çok artırmaya başlamıştır. Bölge haklının nüfus artışını engellemek için kontrollü doğum uygulaması başlatmıştır. Bölgeye daha çok Çinliyi yerleştirerek Uygur Türkleri azınlık haline dönüştürülmüştür.

Doğu Türkistan günümüzde de dahil olmak üzere geçmişten beri Çin'in hammadde ve enerji ihtiyacını karşılayan ana kaynağıdır. Bölgede çıkartılan her doğal kaynak, Çin tarafından işletilmekte ve kullanılmaktadır. Çin’in doğal kaynak ve özellikle de enerjide dışa bağımlı olduğu göze alındığında Doğu Türkistan Çin için önemli olmaktadır.

Doğu Türkistan petrol, kömür ve hidrokarbon doğal kaynakları bakımından çok zengin bir bölgedir. "Çin resmi verilerine göre, Doğu Türkistan'da 5.6 milyar ton petrol, 1.4 trilyon metreküp doğal gaz ve 2,19 trilyon ton kömür rezervi bulunmaktadır. ${ }^{39}$ Öte yandan Doğu

36-Shirley, A. Kan, a, g, e, s, 5.

37-Shirley, A. Kan, a, g, e, s, 5.

38- Yusuf Sayın, Gamze Koçak, “Müslüman Dünyanın Bir Sorun Alanı Olarak Doğu Türkistan Meselesi Ve Çin Halk Cumhuriyeti’nin İzlediği Politikalar”, Journal of Ottoman Civilization Studies, Vol, 3, 2017, s, 19.

39- Omirbek, Hanayi, “Sincan Uygur Özerk Bölgesi’nin Günümüzdeki Ekonomik Yapısı”, Avrasya Araştırma Enstitüsü, Kazakistan, No:86, 2006, s, 1. 
Türkistan, Uzak Doğu ile Avrupa'yı ve Asya’yı, Sibirya ile Güney Asya’yı bağlayan yolların kavşağında bulunmaktadır. Diğer bir deyişle Çin’in dünyaya açılan kapısı konumundadır.

Tüm baskılara rağmen bölge üzerinde güvenlik endişesi yaşayan Pekin yönetimi çevre ülkeler ile ilişkilerini geliştirmek istemektedir. Çünkü Doğu Türkistan’a komşu olan ülkelerin nüfusunun büyük bir kısmı Müslümanlardan oluşmaktadır. Doğu Türkistan’da Müslümanlara uygulanan asimilasyon politikaları doğrudan olmasa da dolaylı olarak Türki devletlerin Çin'e karşı olumsuz bir yaklaşım sergilemelerine neden olma ihtimali vardır. $\mathrm{Bu}$ nedenle Doğu Türkistan sorununu bölgesel anlamda daha sağlam bir zemine oturtabilmek için, 1996'da kurulan Şanghay Beşlisi ( Özbekistan’ın katılmasıyla Şanghay İşbirliği Örgütü adını almıştır), Pekin’in Doğu Türkistan politikalarında elini güçlendirmiştir. ${ }^{40}$ Zira işbirliği gereği bölge ülkeleri, kendi aralarında güven arttırıcı önlemler alma ve sınır sorunlarını çözme konusunda mutabakata varmışlardır. Dolayısıyla bölge ülkelerinin Doğu Türkistan'daki gelişmeler ile ilgili herhangi bir politik söylem ya da faaliyet içinde olmaları engellemiş olmaktadır. ${ }^{41}$

Çin, Şanghay İşbirliği Örgütü çerçevesinde Doğu Türkistan politikasında önemli bir ivme kazanmış olsa da, uluslararası alanda Pekin yönetiminin Doğu Türkistan Politikaları eleştirilmeye devam edilmiştir. Ancak; 11 Eylül saldırılarının yaşanmasıyla, Doğu Türkistan sorunu uluslararası alanda farklı bir boyut kazanarak, Çin lehinde gelişmeler göstermeye başlamıştır. Bu dönemde ABD’nin Taliban ve El Kaide örgütüne savaş açmasıyla, Çin de Uygur Türklerini, El Kaide bağlantılı terörist olarak göstermeye başlamıştır.

İlk olarak, Doğu Türkistan İslam Harekatı'nın (DTİH) terörist faaliyetler içinde olduğunu dünya kamuoyuna duyurmak için, 2001 yılında ilk resmi açıklamasını "Doğu Türkistan teşkilatlarının Usame Bin Ladin ve Taliban ile bağlantıl olarak gerçekleştirdiği terörist faaliyetler" başlıklı bir belge ile yayınland ${ }^{42}$ Çin'in belgeyi yayınlamasından kısa bir süre sonra, BM ve ABD, DTİH’i terörist örgütler listesine almıştır. ${ }^{43}$ Uluslararası alanda kendisine bir fırsat yakalayan Çin, Doğu Türkistan üzerindeki emperyalist statüsünü korumaktır. Pekin yönetimi Doğu Türkistan üzerinde uyguladığı bu gücünü, Çin’in BM Güvenlik Konseyi’nin beş daimi temsilci olması, hızlı büyüyen ekonomisi, nüfusu ve jeopolitik konumundan kaynaklanan gücünden almaktadır.

$\mathrm{Bu}$ pozitif güçleri elinde bulunduran Çin, Doğu Türkistan'daki baskı politikalarına günümüzde de devam etmektedir. Pekin yönetimiÇin’in Doğu Türkistan politikalarına karşı çıkan ya da çıktığını düşünen grupların (Türklerin) bölgede yarattığı isyanları bastırmak amacıyla, askeri birliklerini görevlendirmiştir. Aynı zamanda sivil kişiler arasında haklı ya da haksız olduklarıyla ilgili bir ayrım yapmadan çok sayıda kişiyi tutuklamış veya idam

40-Shirley, A. Kan, a, g, e, s, 30.

41-Selçuk, Çolakoğlu, "11 Eylül Sonrası Değișen Avrasya Dengeleri ve Çin - Orta Asya İlişkileri”, Uluslararası Stratejik Araştırmalar Kurumu, Cilt:1, Sayı: 2, 2006, s, 42.

42-James, Millward, Violent Separatism in Xinjiang: A Critical Assessment, East-West Center Washington, Policy Studies, 6, 2004, s, 11.

43-James, Millward, a, g, e, s, 24. 
etmiştir. Her defasında Doğu Türkistan'la yaşadığı sorunları, kendi iç sorunu olduğunu iddia eden Pekin yönetimi, sorunun çözümünde baskı yolunu seçmektedir. Çin, baskı ve şiddet politikaları ile Türkistan üzerinde egemenliğini sürdürmek istemesi bölgede direniş gruplarının çıkmasına neden olmuştur. Sonuç olarak; Çin baskı, şiddet ve kısıtlama gibi temel ilkeleri kapsamında bölgeyi birleştiremezse bölgenin Orta Asya’nın Filistin’i olması kaçınılmazdır. ${ }^{44}$

\subsection{Uygur Türklerinin Demokrasi Savunucusu: Sürgün Lider Rebiya Kaderr ve Uygur Politikası}

Uygur Türklerinin savunucusu olması ve Çin’in Doğu Türkistan politikasını eleştirmesi, Rebiya Kaderr'in uluslararası alanda tanınmasına ve bir siyasi kimlik kazanmasına neden olmuştur. Eski bir girişimci ve iş kadını olan Kaderr, 1993’ten 1996'ya kadar, Çin Halk Siyasi Danışma Konferansı'nın (CPPCC) resmi üyesi olarak çalışmıştır. ${ }^{45}$ Kaderr’in, Pekin yönetimiyle olan ilişkilerinin bozulması, 1996 yılında Çin’i ziyaret eden ABD Kongre Araştırmaları Heyetinin bir temsilcisiyle görüşmeye giderken tutuklanmasıyla başlamıştır. Akabinde ise 1997'de Halk Kongresinden çıkarılmış, 1998'de CPPCC’ye yeniden seçilmesi yasaklanmış ve yeniden siyaset yapma hakkı elinden alınmıştır. ${ }^{46}$ Hatta Çin'in bir iç problemi olan Doğu Türkistan sorununu bir dış sorun gibi gösterme çabası içinde olduğu için Pekin yönetimi tarafından devlet düşmanı olarak ilan edilmiştir.

Pekin yönetimi, Çin'in iç istikrarını bozmaya çalışan Kaderr’i uluslararası alanda yalnızlaştırmaya çalışırken Avrupalı devletler, Uluslararası Örgütler ve ABD Çin’e karşın Kaderr'in yanında yer alarak, 2005'te serbest kalmasını sağlamışladır. Uluslararası güçlerden destek görerek özgürlüğüne kavuşan Kaderr, bu sefer de ulusal ve uluslararası ödüllere aday gösterilmiştir. 2004 yılında, Norveç tarafından Rafto Barış Ödülüne ve 2006 yılında da Nobel Barış ödülüne aday gösterilmiştir. ${ }^{47}$

2005'te Uluslararası Uygur İnsan Hakları ve Demokrasi Kuruluşu'nu kurması, 2006 yılında Uygur Amerikan Derneği'nin başkanı seçilmesi, 2006'da ise Münih’te kurulan Dünya Uygurlar Kongresi başkanı seçilmesi, Kaderr’i Çin karşısında daha güçlü konuma yükseltmiştir. Bu durum hiç şüphesiz Çin’in Doğu Türkistan’la ilgili politikalarını güçsüzleştirirken Kaderr’in Çin’e karşı yürüttüğü Doğu Türkistan politikasını güçlendirmiştir. Çin Komünist Partisi’nin en büyük halk düşmanlarından birisi olan Kaderr, Pekin yönetiminin tüm engellemelerine rağmen Uygur Türklerinin

44- Michael Clarke, "China and the Uyghurs: The "Palestinization" of Xinjiang?", Middle East Policy Vol. XXII, No. 3, 2015, s, 128.

45-Fatih, Şen, "Uluslararası Tepkiler Açısından Sincan Uygur Sorunu”, Orta Doğu Analiz, Eylül, 09 Cilt 1, Sayı 9, 2009, s, 113.

46- "People's Republic of China: Xinjiang Uighur Autonomous Region Appeal for Uighurs Arbitrarily Detained", Amnesty International Report, 2011, s, 6.

47-Guang, Tian, Debat, Mahesh Ranjan, "Identity and Mobilization in Transnational Societies: A Case Study of Uyghur Diasporic Nationalism”,Central-Asia Caucasus Institute Silk Road Studies Program, Vol 8, No, 4, 2002, $s, 70$. 
savunuculuğunu yapmaktadır. Dünya Uygur Türkleri kongresine liderlik eden Kaderr, yabancı hükümetler ve sivil toplum kuruşları ile lobi yaparak Uygurların sesini dünyaya duyurmaya çalışan bir aktivisttir.

Kaderr, Uygurların hak savunuculuğunu çatışma ortamından uzak ama aynı zamanda da Çin’i baskı altına alarak yürütmektedir. Öncelikle uluslararası toplum tarafından Çin’i baskı altına almayı amaçlamaktadır. Bunun için Çin üzerinde baskı yapabilecek yetkinlikte olan $\mathrm{ABD}$ ve Almanya gibi ülkeler ilişkiler geliştirmektedir. Bu ülkelerde kurulan örgütlere liderlik yaparak bu ülkeler üzerinden Uygurların sorunlarını uluslararası kamuoyuna duyurmaktadır. Bu politikası sayesinde Doğu Türkistan'da yaşanan katliamları tüm dünyaya duyurmayı başarmıştır. Ancak katliamların durmasını sağlayamamıştır. Bir diğer politikası, Tayvan ve Tibet haklarını Çin’in ihlallerine karşı bilinçlendirmesidir.

Kaderr'in bu politikası Pekin yönetimini en fazla düşündüren ve rahatsız edenidir. Kaderr’in, 2017 yılında Tayvan Dayanışma Birliği tarafından konuşmacı olarak Tayvan’a davet edilmesi Çin’in tepkisine neden olmuştur. Zira Tayvan Çin ilişikleri iyi değildir. Çin, Tayvan'ı ve Tibet'i de içeren "Bir Çin” politikası altında yeniden birleştirilmesi gereken bir bölge olarak görmektedir. Dolaysıyla Pekin yönetiminin tepkisinden çekinen Taipei yönetimi Kaderr'e vize vermemiştir. ${ }^{48}$

Çin'in iç politikada en fazla önem verdiği sorun ayrılıkçı etnik gruplardır. Zira Çin'de çok sayıda $(56)^{49}$ etnik grup vardır. Bu etnik grupların bağımsızlık istemesi veya Pekin yönetimine karşı ayaklanması Çin'de iç siyasal istikrarın bozulmasına yol açacaktır. Çin Doğu Türkistan’a bağımsızlık ya da özerlik verdiği takdirde Tibet de Pekin yönetiminden aynı hakları isteyecektir. Bu durum Çin ve Çin Komünist Partisi'nin geleceğini tehdit etmektedir. Dolayısıyla Pekin yönetimi Doğu Türkistan’a bağımsızlık vermeyecektir.

Kaderr'in tüm bu çabalarına karşın Pekin yönetimi baskıcı tutumunu devam ettirmektedir. Bölgede şu an için barış ya da uzlaşma mümkün değildir. Çin'in Doğu Türkistan'daki çıkarları devem ettiği ve bölgedeki direniş gruplarının terör faaliyetleri içinde olduğu uluslararası toplum tarafından kabul edildiği sürece, Doğu Türkistan, Çin hegemonyası altında uzun yıllar boyunca yönetilecektir. Bu nedenle ileriki yılarda da bir barış ortamının beklenilmesi zor gözükmektedir. Kaderr’in Pekin yönetimine karşı yürüttüğü Doğu Türkistan politikası, şu an için başarısız olmaktadır. Kısa vadede kalıcı barışın sağlanması Pekin yönetiminin tutumundan dolayı olası bir durum değildir. Barışın olmadığı durumda ülke halkının daha müreffeh bir ortamda yaşaması mümkün olmadığ 1 gibi Kaderr’in de Doğu Türkistan sorununa bir çözüm bulması imkansızdır. Kaderr'in Tayvan ve Tibet'teki etnik gruplar üzerinden Doğu Türkistan politikasına son vermesi gerekmektedir. Uygurların Çin’e bağlı olduğu ancak temel haklarının geri verilmesi gerektiğini Pekin yönetimine açıkça belirtmesi gerekir. Kaderr tarafından bu atılımlar

48- China warn Taiwan on Rebiya Kadeer invite; invites Taiwanese to live, work on mainland, http://www.tibetanreview.net/china-warn-taiwan-on-rebiya-kadeer-invite-invites-taiwanese-to-live-work-on-mainland/, erişim tarihi:15.10.2018.

49- Shenghai He, “An Overview of China’s Ethnic Groups and Their Interactions”, Sociology Mind, 2017, s, 1. 
gerçekleştirildiği takdirde Pekin yönetimi Uygulara baskı yapmayabilir veya Uygurlara temel hakları geri verilebilir.

Öte yandan Pekin yönetimi tüm bu uzlaşma yollarını kapatırsa haklı olarak bölgedeki direniş grupları temel haklarını savunmak için silahlı eylemleri seçmek zorunda kalacaktır. Tüm dünyada cihat adı altında birbirlerine destek veren grupların var olduğu düşünüldüğünde Doğu Türkistan İslam Harekatı'na da destek verilme ihtimali yüksektir. Resmi olmayan kaynaklara göre Taliban ve DEAŞ gibi terör örgütlerinden destek alındığı düşünülmektedir. ${ }^{50}$ Bundan dolayıdır ki Türkistan’ın yakın bir zamanda Filistin kurtuluş örgütünün İsrail'e savaş açtı̆̆ 1 gibi Doğu Türkistan İslam Harekatı’nın da Pekin yönetimine savaş açacağ 1 dile getirilmektedir. Bir nevi Doğu Türkistan'da intifada gerçekleştirilecektir. ${ }^{51} \mathrm{Bu}$ senaryonun yaşanmaması için Pekin yönetimi ve Kaderr ortak mutabakata varmalıdırlar. Aksi takdirde ezilen halk meşru haklarını kazanabilmek için saldırı eylemlerinde bulunabilir. Savaşın yaşanması halinde bölgede yoğun katliamlar olacaktır. Sonuç olarak; Kaderr'in yapması gereken, gereğinden daha fazla uluslararası alanda güçlü ülkelere ziyaretlerde bulunarak Uygur Türklerinin kendi hak arayışları dışında Pekin yönetimine karşı herhangi bir silahlı eylemde bulunmadıklarını belirtmesi gerekmektedir. Doğu Türkistan’ın bağımsız bir devlet ya da özerk bir yapı altında yönetilmek istemediğini açıkça belirtmesi gerekir. Böylece Pekin yönetimi Doğu Türkistan politikasında bir yumuşama sürecine geçebilir.

\section{SONUÇ}

Çalışmada ele alınan konu kapsamında şu değerlendirmeleri yapmak mümkündür: Çalışma genel olarak Asyalı kadın siyasal figürlerin ülkelerinde bir değişimin parçası olabilecek mi sorusuna cevap aramaktadır. Bu doğrultuda Asya kıtasında iki ülke seçilmiştir. Bunlar Myanmar ve Doğu Türkistan'dır. Myanmar ve Doğu Türkistan'da yaşanan olaylar üzerinden ele alınan örnekleri, Asya’nın diğer ülkelerinden ayıran temel farklılıklar; bu iki ülkenin demokrasi ile yönetilmemesi, ülke halklarının temel haklarının ellerinden alınması, uluslararası toplumun gözü önünde devlet destekli katliamların yapılması ve kadın siyasi figürlere baskı yapılması gibi nedenler bu iki bölgenin kadın siyasi figürlerini diğer Asya ülkelerinin kadın figürlerinden ayrıcalıklı kılmaktadır.

Gerçek demokrasilerden bahsedebilmek için kadınların toplumsal hayatın her alanında olması gerektiği savunulmaktadır. Ancak olması gereken ile olan arasında büyük bir tezatlık vardır. Teoride demokrasilerin gelişimi için kadınların daha çok görevler yüklenmesi beklenirken realitede kadınların siyaset yapmasını kısıtlayıcı pek çok neden vardır. Bu nedenler arasında en dikkat çekeni kota politikalardır. Zira kota politikasıyla kadınlar siyasetin dışına doğrudan itilmektedir.

50- Michael Clarke, a, g, e, s, 129.

51- Michael Clarke, a, g, e, s, 129. 
Siyaset yapmak isteyen kadınların; evli olmaları, siyasi ofislerinin olmayışları, ekonomik açıdan güçlü olmayışları, siyaset yapmak için yeterli zamanlarının olmayışı ve hemcinslerinin kadın siyasi liderlere güvenmeyişi kadın siyasetçilerin önündeki diğer engellerdir. Diğer bir neden ise siyasetin işleyişi ile alakalıdır. Siyaset her şeyden önce gönüllülük esasına dayamaktadır ve uzun soluklu bir süreci kapsamaktadır. Bu anlamda kadınların siyaset yapması için öncelikle gönüllü olması ve uzun bir süreci kapsadığı için de emek harcamaları gerekmektedir. Aksi takdirde siyaset yarışının dışında kalabilirler. Yapılan bu değerlendirmeler dünya genelinde tüm kadın liderlerin karşılaştığı temel sorunlardir.

Asya kıtası geleneklerine bağlı ve gelişmekte olan bir kıtadır. Kıta ataerkil yönetim şekline sahiptir. Dolayısıyla erkeğin egemen olduğu bir coğrafyada kadınların siyasal hayata katılması pek kolay bir şey değildir. Tüm bu olumsuzluklara rağmen Asya kıtasında kadın aktörler geçmişte olduğu gibi günümüzde de devlet yönteminde yer almışladır. Hatta bazıları uzun yıllar ülke yönetiminde bulunmuşladır. Şu an için Asya kıtasında topyekün bir kadın aktör değişiminden bahsedemeyiz. Ancak yeni kadın aktörlerin ortaya çıkışı gelecek yıllar için umut vaat etmektedir.

Çalışmada ele alınan kadın siyasal figürler Pekin ve Rangoon yönetimlerinin Doğu Türkistan ve Arakan politikaları nedeniyle ülkelerinde bir değişimin parçası olamayacaklardır. Ancak ülkelerinde demokrasi mücadelesi vermek istiyorlarsa bu kadın aktörlere burada bazı görevler düşmektedir. Öncelikle kimlik ayrımı yapmadan ülkelerindeki tüm halkı kapsayacak politika üretmelidirler. Uluslararası platformlarda Myanmar ve Doğu Türkistan ile ilgili düşüncelerini daha iyi anlatarak çatışmanın sadece halka değil aynı zamanda ülkeye de zarar verdiğini dile getirmelidirler. Çünkü Pekin ve Rangoon yönetimleri çatışmaları bastırırken arkada düşman bir toplum bırakmaktadır. Bu da Myanmar ve Doğu Türkistan'da kalıcı sorunların bugün değilse bile ileriki zamanlarda tekrar ortaya çıkabileceği ihtimalini göstermektedir. 


\section{KAYNAKÇA}

Abanti, Bhattacharya, (2003). "Conceptualising Uyghur Separatism in Chinese Nationalism” Institute for Defence Studies and Analyses, Strategic Analysis, Vol. 27, No. 3.

Bangladesh Refuses Entry to Myanmar Refugees, (2017). https://aawsat.com/english/home/article/1011261/ bangladesh-refuses-accept-more-rohingya-refugees-fleeing-myanmar erişim tarihi: 16.08.2018

Burma Human Rights Yearbook, (2003). Government Printing Office National Coalition Government of the Union of Burma.

Burma police clash with Muslim protesters in Maung Daw, (2017). http://www.bbc.com/news/world-asia-18368556, erişim tarihi: 14.08.2018.

"Burma the 18 September 1988 Military Takeover and Its Aftermath"(1998). Amnesty International http://wwwibiblio.org/obl/ docs3/18_Sept_1988-ocr.pdf, erişim tarihi:15.07.2018.

“China’s Myanmar Dilemma”(2000). Interanational Crisis Group Asian Report, No, 177.

China warn Taiwan on Rebiya Kadeer invite; invites Taiwanese to live, work on mainland, http://www.tibetanreview.net/chinawarn-taiwan-on-rebiya-kadeer-invite-invites-taiwanese-to-live-work-on-mainland/, erişim tarihi:15.10.2018

Clarke, Michael, (2015), “China and the Uyghurs: The “Palestinization” of Xinjiang?” Middle East Policy Vol. XXII, No. 3.

Çolakoğlu, Selçuk, (2006). "11 Eylül Sonrası Değișen Avrasya Dengeleri ve Çin - Orta Asya İlişkileri”, Uluslararası Stratejik Araştırmalar Kurumu, Cilt:1, Sayı: 2.

Devi, Konsam Shakila, (2014), Myanmar under the Military Rule 1962-1988, International ResearchJournal of Social Sciences Vol. 3.

Ekeh Chizom,(2007). “Minorities in Burma”, Minority Rights Group International, England.

Geiger, Abigail, (2017), Number of Women Leaders Around the World has Grown, But They're Still a Small Group, Pew Research Center.

Gutter, P and Sen B.K.(2001). “Burma's State Protection Law", Burma Lawyers' Council, Bangkok 10243, Thailand.

Hanayi, Omirbek, (2006), "Sincan Uygur Özerk Bölgesi’nin Günümüzdeki Ekonomik Yapısı", Avrasya Araștırma Enstitüsü, Kazakistan, No:86.

He, Shenghai, (2017), "An Overview of China’s Ethnic Groups and Their Interactions", Sociology Mind.

Hillman, Ben, (2017), "Increasing Women's Parliamentary Representation in Asia and the Pacific:The Indonesian Experience", Asia \& the Pacific Policy Studies.

"History of Burma, (2005). From a Multi- Ethnic Perspective", The Cirriculum Project.

Kallie, Szczepanski, (2018), "Female Heads of State in Asia." ThoughtCo.

Karaca, R, Kutay, (2007) “Türkiye-Çin Halk Cumhuriyeti İlişkilerinde Doğu Türkistan Sorunu” Akademik Bakış.

Kan, A. Shirley, (2010). "U.S.-China Counter terrorism Cooperation: Issues for U.S. Policy", Congressional Research Service.

Kivimäki Timo, Pedersen, B. Morten, (2000) Burma: Mapping the Challenges and Opportunities for Dialogue 
and Reconciliation, Crisis Management Initiatives, Belgium.

Lian, H Sakhong, (2019), "The Dynamics of Sixty Years of Ethnic Armed Conflict in Burma”Burma Center for Ethnic Studies Peace and Reconciliation, Analysis Paper No.1.

Millward, James, (2004). Violent Separatism in Xinjiang: A Critical Assessment, East-West Center Washington, Policy Studies 6.

"Myanmar: The Military Regime'sView of the World, (2001)."ICG Asia Report, No 28.

Myanmar: UN Security Council Must Impose Arms Embargo,https://www.amnesty.org/en/pressreleases/2017/09/myanmar-un-security-council-must-impose-arms-embargo/ erişim tarihi:16.08.2018

Myanmar's Suu Kyi - from housewife to democracy hero https://www.reuters.com/article/ idINIndia-52870120101112 erişim tarihi:13.08.2018

Iwanaga, Kazuki, (2008), "Women's Political Participation and Representation in Asia" Nordic Institute of Asian Studies.

"People's Republic of China: Xinjiang Uighur Autonomous Region Appeal for Uighurs Arbitrarily Detained Report",(2001). Amnesty International.

Political situation in Burma, The House of Commons Library,(2016). Number CDP 2016-0071 | 21 March, England.

Sayın, Yusuf, Koçak, Gamze, (2017), "Müslüman Dünyanın Bir Sorun Alanı Olarak Doğu Türkistan Meselesi Ve Çin Halk Cumhuriyeti’nin İzlediği Politikalar”, Journal of Ottoman Civilization Studies, Vol,3.

Song, Jiyoung, (2016), “The Challenge for Asia's Female Politicians", The Diplomat, s, 1-3

Steckman, Laura, (2015). Myanmar at the Crossroads: the Shadow of Jihadist Extremism, International Centre for Political Violence and Terrorism Research, Singapore.

Steinberg, I. David, (2010), "Aung San Suu Kyi and U.S. Policy toward Burma/Myanmar", Journal of Current Southeast Asian Affairs, s, 38

Sun, Yun, (2014). Myanmar's ASEAN Chairmanship, Stimson Center, Great Powers and the Changing Myanmar Issue Brief No. 4 September.

Sutter, Robert, (2012), "Myanmar in Contemporary Chinese Foreign Policy-Strengthening CommonGround, Managing Differences",Journal of Current Southeast Asian Affairs,

Şen, Fatih, (2009). “Uluslararası Tepkiler Açısından Sincan Uygur Sorunu”, Orta Doğu Analiz, Eylül,09 Cilt 1 - Say1 9.

Tian, Guang, Ranjan Mahesh, (2002).Debat, "Identity and Mobilization in Transnational Societies: A Case Study of Uyghur Diasporic Nationalism",Central-Asia Caucasus Institute Silk Road Studies Program,Volume, $8, \mathrm{No}, 4$.

Tür, Özlem, Koyuncu, Aydın, (2010). Çiğdem, "Feminist Uluslararası İlişkiler Yaklaşımı: Temelleri, Gelişimi, Katkı ve Sorunları", Uluslararası İlişkiler Dergisi, Cilt 7, Sayı 26. 
"US Department of State Self Study Guide for Burma” (2010).United States Department of State Washington, D.C.

Yunus, Muhammed, (1994). A History of Arakan: Past and Present, Magenta Colour. "Rebiya Kadeer Has Been Released" (2005). Amnesty International.

Zaiton, Johari, (2000).The Role of the Tatmadaw in Modern Day Burma: An Analysis, Naval Postgraduate School, California.

Why is Aung San Suu Kyi silent on the plight of the Rohingya people? https://www.theguardian.com/world/2015/ may/19/why-is-aung-san-suu-kyi-silent-on-the-plight-of-the-rohingya-people erişim tarihi: 16.08.2018

Women in Parliament: 20 years in review, Inter-Parliamentary Union, http://archive.ipu.org/pdf/publications/ WIP20Y-en.pdf, erişim tarihi:10.07.2018 